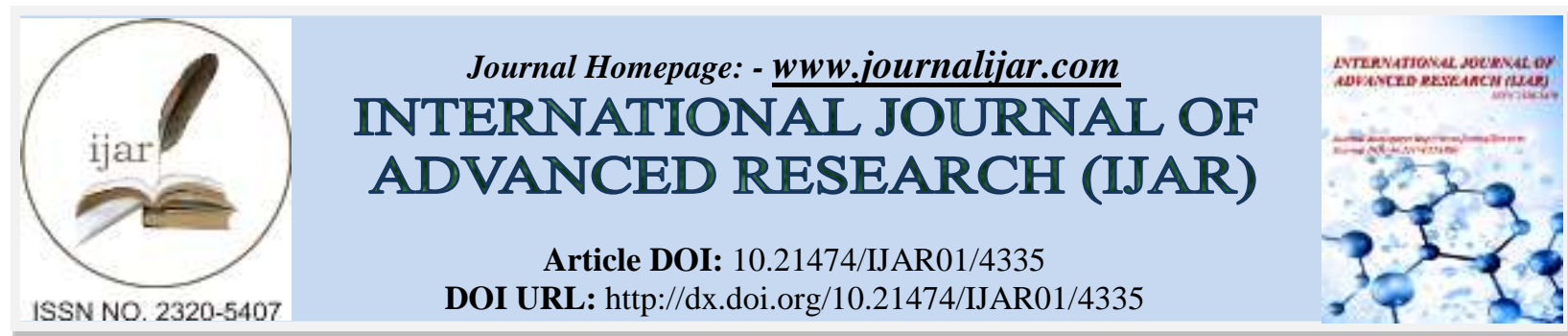

RESEARCH ARTICLE

\title{
EFFECT OF INTRA ROW-SPACING ON MALT BARELY VARIETIES (HORDEUM VULGARE L) ON YIELD PERFORMANCE AT GITILO RESEARCH SITE AND JARTE WERDAS FARMERS' FIELD, WESTERN ETHIOPIA.
}

\begin{abstract}
Alemu Beyene.
College of Agriculture Wilkega University.

\section{Manuscript Info}

........................

Manuscript History

Received: 19 March 2017

Final Accepted: 15 April 2017

Published: May 2017

Key words:-

Intra row, varieties, malt barley, location and yield.

\section{Abstract}

Malt barely is one of the cereal crops that are dominantly cultivated for beer beverage or beer factors. So that farmers in high land area of Ethiopia is mainly produce as cash crop. While the production of malt barely crops are still not fit the requirement of malt factors due to certain agronomical problems like space between plant, agro ecological requirement of the crops and lack of improved varieties of the crops are the major challenges for malt barley production in the country. The research work was conducted at Gitilo research site and Jarte Farmers field of Western Oromia Regions state to determine the appropriate intra-row spacing for malt barely varieties at the study areas and to evaluate the growth and productivity of malt barely varieties at the study site. The experimental material to be used Ibon, Bahite and Holker varieties of malt barely was obtained from Kulumisa Agricultural research center. The seed was sown at $10 \mathrm{~cm}$, $15 \mathrm{~cm}, 20 \mathrm{~cm}$ and $25 \mathrm{~cm}$ intra row spacing at both study site and the field lay out was arranged as Randomized Complete block design with three replication. The experimental procedures likes land preparation, sowing, weeding, fertilizer application, harvesting and threshing was done uniformly at appropriate time under field condition. The phonological, growth and yield data data's were collected from the field at a time and the collected dates were analyzed by statically procedures SAS 9.1 version soft ware and the treatment mean was separated at $0.05 \%$ probability level. The analysis of variance was significant effect on the phonological and growth parameters while the yield parameters were non-significant difference on malt barley crop. The analysis of variance on location, varieties and interaction effect were shown significant difference $(p<0.05)$ on grain yield. But the main effect of intra row spacing was significantly difference $(\mathrm{P}<0.01)$ on grain yield of malt barely crop. The highest grain yield 33.6qu/ha was measured at $10 \mathrm{~cm}$ intra row spacing on Ibon variety of malt barely at Gitilo site. But the lowest grain yield $25 \mathrm{~cm}$ was measured at intra row spacing of Bahite variety of malt barely at Jarte study site. Moreover at narrow plant spacing high amount of malt barely productions was registered at Gitilo study site. Therefore at $10 \mathrm{~cm}$ intra row spacing Ibon variety of malt barley is more recommendable at gitilo study site.
\end{abstract}


Copy Right, IJAR, 2016,. All rights reserved.

\section{Introduction:-}

Barely (Hordeum vulgare L) is one of the important cereal crop cultivated all over the world except some tropical countries. They are two type of barely crops are produced in the high and mid land of barely producing regions; among that food barely varieties are mainly cultivated for human consumption. It is the major food for large numbers of people living in the cooler and semi-arid areas of the world where wheat and some other cereals less adopted (Asmare et al., 1998).

Malt barely crops are adapted at altitude above $2800 \mathrm{~m}$ and requires cool weather condition $\left(12-15^{\circ} \mathrm{C}\right)$ during growing period and warm $30^{\circ} \mathrm{C}$ dry weather condition during maturity (Acqual, 2005). It grows well in tropical and sub tropical climates, but cannot withstand forest at any stage especially at flowering. The crops are tolerating to drought and sodic soil conditions. It is mostly under rain fed/ dry land conditions. The soil requirements for barely production are sandy loam to heavy loam soils, while acidic soils are not fit for barely production (Miller, 1999). Apart from industrial use such as malting, brewing barely is consumed by human beings in many forms. As 'buscuit' for infants and sick person, barely water is very useful. Barely is more digestible as compared to wheat because it doesn't contain gluten. Barely also used as grain feed for livestock, and poultry and straw as cattle feed. Both food and malt barely are produced in the country at national level currently, 984,943ha of land is covered by food and malt barley and over 13,548,071 quintals are produced (EIAR, 2007). However, its production has not extended in all barely producer's area, and productivity at farm level has remained low (CSA, 2010).

One of the most drastically yield reduction in malt barely crops at the study areas are lack of improved seed, poor field management practices, farmers at study areas sown barely crops through broad cast method theses it causes high plant population per plot of land and lodging effect on crops in other side the plant compete among them for natural resource, absence of technology, lack of awareness, and due to these and other problems farmers in the study areas give less attention to producing malt barely crops at high land areas.

Other factors like diseases incidence, insect pest and weed problems are highly reduce the production of malt barely for instance stem and leaf rust, head blight, black point, foliar disease, powdery mildew, leaf blotch, and stripe blight of barely diseases are highly influence the production of barely. Certain insect like weevils are highly injure the malt barely yield at storage site, aphid and wire worm at the field site also decline the quality and marketability of barely at study area (ORDA, 2008a). Therefore, these research work was solved the problems of malt barely production at the study areas through create awareness and introduce the specific intra row spacing for malt barely crops.

\section{The objectives:-}

- $\quad$ To determine the appropriate intra-row spacing for malt barely varieties at the study areas.

- To evaluate the growth and productivity of malt barely varieties at the study site.

\section{Material and Methods:-}

\section{Description of Experimental Site:-}

The field experiment was conducted at Horro Guduru Wollega Zone Jarte farmers filed and Gitilo Research sites, during rainy season 2015/16. The farming area is located in Horro Guguru Wollega Zone, Oromia Regional State and far away from Addis Ababa city by $332 \mathrm{~km}$ the Western part of Ethiopia.

The study area was characterized by mono-modal rain fall distribution for six month from April - October and the area receives the averages annual rainfall ranging from 1900-2100mm. The mean annual temperature of the study areas ranges $12-20^{\circ} \mathrm{c}$. The cropping patterns of the study sites was dominantly cereals crop, the soil is clay loam textural class according to a report of (HGZAB, 2010).

\section{Description of experimental Material:-}

The improved malt varieties (Ibon, Bahati, and Holkar) were obtained from Qulumisa Agricultural Research Center. The crop was matured within 112-145 days depend up on the rain fall distribution and altitude of the areas. Also it adapts to different agro ecological zone ranges between 2000-2800masl, and the rain fall requirement of the crops ranges 500-2500mm per annual. In generally the amount of yield was obtained per a hectors of land was different 
from varieties to varieties and it ranges 24- 45 quintals at the research site and 15- 35 quintals at the farmer's site. The crop was more tolerant to lodging, vigorous and has response to phosphorus fertilizer and low to nitrogen (MoARD, 2008).

\section{Treatment and experimental Design:-}

The experiment was consisted three improved varieties of malt barely seed with four intra- row spacing was sown at Gitilo research site and Jarte farmer's field. The experiment was laid out as a Randomized Complete Block Design (RCBD), with three replications. The seed of barely varieties was planted in $2 \mathrm{~m}$ length; $30 \mathrm{~cm}$ inter spacing and $10 \mathrm{~cm}, 15 \mathrm{~cm}, 20 \mathrm{~cm}$ and $25 \mathrm{~cm}$ intra row-spacing with 5 rows and broadcasting sowing method also practices for improved and local varieties as control.

The gross plot size for barely seeding $\left(2 \mathrm{~m} \times .30 \mathrm{~m} \times 5\right.$ rows $\left.=4 \mathrm{~m}^{2}\right)$ and from the three central rows $(3$ rows $\mathrm{x} 0.30 \mathrm{~m} \times$ $2 \mathrm{~m}=1.8 \mathrm{~m}^{2}$ ) the data was collected.

\section{Experimental Procedure:-}

Land was tilled during May, 2005 three to four times by using of animals power. The seed bed was prepared and the improved malt barely varieties were drilled along the furrow at inter spacing of $30 \mathrm{~cm}$ at plant depth of $5 \mathrm{~cm}$ simultaneously in the first week of July, 2015. Nutrients required for plants growths like nitrogen and phosphorus fertilizers was applied at the rate of $40 \mathrm{Nkg} / \mathrm{ha}$ and $80 \mathrm{Pkg} / \mathrm{ha}$. Application of high amount of nitrogen fertilizer as well as the plant highly infested by weed can decrease the quality of malt barley. Also the amounts of fertilizer applied to the soil vary due to crop rotation, irrigation facility to be used, crops to be required and amount of fertilizer exists in the soil. So, the DAP fertilizers will be applied at time of sowing. All other managemental practice was done uniformly.

Data to be Collected:-

\section{Phonological and growth Parameters:-}

The following selected phonological stages, growth and yield parameters data was recorded for malt barely varieties.

\section{Days to $50 \%$ crop flowering, and days to $90 \%$ Maturity:-}

The data was recorded when $50 \%$ and $90 \%$ of the plants within a plots reached the respective phonological stages.

Plant Height:- The plant height was measured in $\mathrm{cm}$ from five plants randomly sampled from the central rows at dough growth stage. The total measured plant height was summed together and divided by the numbers of plant to get height per plant.

\section{Number of tillers:-}

The numbers of tillers produced per plant was counted in five randomly selected plants at physiological maturity stage.

\section{Above ground Biomass:-}

The above ground biomass was recorded from all plants per plot and sun drying at a constant weight.

\section{Yield component and Yield:-}

Number of seed per spike:-

The number of seed produced per spike was recorded from the randomly sampled five plants per net plot area at harvesting.

\section{Spike length (cm):-}

The spike length of barely plant was measured by randomly sampled five plants per net plot at harvest.

\section{Thousand grain weight (g):-}

Count two samples of 250 grain from each plot by weigh the samples separately and add to get 500 seed weight. Then multiply to get 1000 seed weight adjusted to $8 \%$ moisture. 


\section{Grain yield (g):-}

The grain yield per plot area was weighed in gram or kilograms and converted in to hectares bases and adjusted to $10 \%$ moisture level.

\section{Harvest Index (\%):-}

Harvest index of barely crop was calculated as the ratio of grain yield $(\mathrm{kg})$ to above ground dry biomass $(\mathrm{kg})$ per net plot and multiplied by $100 \%$.

\section{Data Analysis:-}

The data collected for malt barely crop was subjected to analysis of variance using statically procedures as described by Gomez and Gomez (1984) using SAS program. Difference between treatment means was compared using least significance difference (LSD) test at 5\% level of significant when ANOVA shows the presence of significant difference.

\section{Result and Discussion:- \\ Malt barely Component:- \\ Malt barley crop phenology:-}

The analysis of variance on phonological parameters was significant effect on main treatment. The main effect of malt barely varieties and locations were highly significantly affected $(\mathrm{P}<0.01)$ on days to $50 \%$ flowering, but intrarow spacing were significant $(\mathrm{P}<0.05)$ difference on $50 \%$ days to flowering on malt barely crops (Table 1$)$. The interaction effect of location with varieties was highly significant difference on malt barely crops, while the interaction of location with intra row spacing, varieties with spacing and the interaction of the three treatment was non- significant influenced $(\mathrm{P}>0.05)$ by the study sites. The longest days to $50 \%$ flowering $(82.4$ days) were observed on Holker variety at intra row spacing of $25 \mathrm{~cm}$ at gitilo study site. While the shortest days to $50 \%$ flowering was recorded at $10 \mathrm{~cm}$ intra row plant spacing on Bahite variety of malt barely at Jarte farmers field. The control treatment was non significant difference on days to 50\% flowering. This finding agrees with the study of Van Deynze et al., 1992. Increasing intra row spacing on malt barely crops delayed the days to $50 \%$ flowering on rape seed varieties.

Table 1:- Interaction effect of intra row spacing with location of malt barely varieties on days to $50 \%$ flowering.

\begin{tabular}{|c|c|c|c|}
\hline \multicolumn{3}{|c|}{ Varieties of malt barely } \\
\hline Location & $\underline{\text { Ibon }}$ & $\underline{\text { Bahite }}$ & $\underline{\text { Holker }}$ \\
\hline Gitilo & $79.7^{\mathrm{b}}$ & $87.1^{\mathrm{a}}$ & $90.8^{\mathrm{a}}$ \\
\hline Jarte & $75.3^{\mathrm{b}}$ & $75.2^{\mathrm{b}}$ & $74 \mathrm{a}^{\mathrm{b}}$ \\
\hline Lsd $0.05 \%=* *$ & & & \\
\hline Cv\%=4.29 & & & \\
\hline
\end{tabular}

The mean followed by the same letters are non significant difference at $0.01 \%$ probability.

The reason why delaying in days to 50\% flowering on malt barely varieties are because of genetic difference of malt barely crops, plant population and adaptation to different agro-ecological zone. As the plant population per hectares of malt barely crops are increased the days to 50\% flower producing on malt barely crops are shorter because of scarcity of resource, like water and nutrients element. While as the malt barely plant grown under wider intra row spacing the days to $50 \%$ flowering was relatively longer due to less compete for resource. Even through at the high land area days to $50 \%$ flowering on malt barley crop were delayed due to the lower in mean annul temperature as compared to low land areas. The interaction of location, intra row spacing and malt varieties were non-significant difference ( $p>0.05$ ) on days to $50 \%$ flowering of malt barely crops at the study sites.

The analysis of variance on day to $90 \%$ maturity of malt barley crop was non significant $(>0.05)$ (Table 1$)$ difference on main effect and interaction effect of malt barely crops.

Table 3:- The interaction effect of location with varieties on plant height malt barely crop

\begin{tabular}{|c|c|c|c|}
\hline \multicolumn{3}{|c|}{ Malt barely varieties } \\
\hline Location & Ibon & Bahite & Holker \\
\hline Gitilo & $82.25^{\mathrm{d}}$ & $87.66^{\mathrm{c}}$ & $102.58^{\mathrm{b}}$ \\
\hline Jarte & $85.91^{\mathrm{c}}$ & $85.83^{\mathrm{c}}$ & $109.16^{\mathrm{a}}$ \\
\hline Lsd $(0.05 \%)=5.13$ & & & \\
\hline Cv\%=5.01 & & & \\
\hline
\end{tabular}


The mean followed by the same letters are non significant difference at $0.05 \%$ probability

The analysis of variance on malt barley crop was shown significant difference on growth parameters. The treatment effect of malt barely varieties were highly significant $(\mathrm{P}<0.1)$ difference on plant height (Table 2$)$, while the treatment effect of location and intra row spacing was significant difference $(\mathrm{P}<0.05)$ on plant height of malt barely. The interaction effect of location with varieties was significant difference $(p<0.05)$ on plant height, but the interaction of location with spacing, varieties with spacing, and the interaction of three treatments were non significant difference $(\mathrm{P}>0.05)$ on plant height of malt barely (Table 2). The highest plant height $(95.44 \mathrm{~cm}$, $105.85 \mathrm{~cm}$ and $93.63 \mathrm{~cm}$ ) were measured at intra row spacing of $10 \mathrm{~cm}$ on Holker variety of malt barely at Gitilo study site respectively. While the shortest plant height $(90.27 \mathrm{~cm}, 84.08 \mathrm{~cm}$ and $90.83 \mathrm{~cm})$ were measured at $25 \mathrm{~cm}$ intra row spacing on Bahite variety of malt barely at Jarte farmers' field. The reason why plant height of malt barely varieties different is due to variation of climatic factors, agronomic practices, crop variety and soil fertility status of the study site. Plant height of malt barley crop was shorter at wider intra row spacing because of less competition for resource, as the result the crop produce high amount of tiller per plant.

Table 4:- The interaction effect of location, intra row spacing and varieties of malt barley on number of tiller produced per plant

\begin{tabular}{|c|c|c|c|c|c|}
\hline & & & Intra row & & \\
\hline Location & $10 \mathrm{~cm}$ & $15 \mathrm{~cm}$ & $20 \mathrm{~cm}$ & $25 \mathrm{~cm}$ & Varieties \\
\hline 1 & $5.3^{\mathrm{c}}$ & $6^{\text {bc }}$ & $7.6^{\mathrm{a}}$ & $8.3^{\mathrm{a}}$ & 1 \\
\hline 1 & $4^{\mathrm{d}}$ & $4.6^{\mathrm{d}}$ & $5^{\mathrm{c}}$ & $5.3^{\mathrm{c}}$ & 2 \\
\hline 1 & $3.6^{\mathrm{e}}$ & $4.3^{\mathrm{d}}$ & $5.3^{\mathrm{c}}$ & $6.3^{\mathrm{b}}$ & 3 \\
\hline 2 & $3.6^{\mathrm{e}}$ & $5^{\mathrm{c}}$ & $5^{\mathrm{c}}$ & $6.3^{\mathrm{b}}$ & 1 \\
\hline 2 & $4.3^{\mathrm{d}}$ & $5^{\mathrm{c}}$ & $5.3^{\mathrm{c}}$ & $6.3^{\mathrm{b}}$ & 2 \\
\hline 2 & $5.3^{\mathrm{c}}$ & $5.3^{\mathrm{c}}$ & $6^{\mathrm{bc}}$ & $6.6^{\mathrm{b}}$ & 3 \\
\hline $\operatorname{LSD}(0.05 \%)=0.75$ & & & & & \\
\hline $\mathrm{Cv} \%=14.39$ & & & & & \\
\hline
\end{tabular}

The mean followed by the same letters are non significant difference at 0.05 probability level

In contrary at narrow intra row spacing the plant competes for natural resource like water, nutrient and light energy. Under such condition in order to survive the plant competes more amount resource. Certain hormones that help for plant growth like Cytokines are motivated in the presence of light energy. Holker varieties are higher in plant height at both study sites while Ibon and Bahite varieties are relatively medium in plant height at both locations.

The agro ecology of gitilo study site is relatively higher in altitude and the mean annual temperature is low and high moisture holding capacity as compare to jarte study site. The height of malt barely is higher at gitilo study area.

Table 5:- The interaction effect of location, intra row spacing malt barley varieties on number of seed produced per spike.

\begin{tabular}{|c|c|c|c|c|}
\hline \multicolumn{5}{|c|}{ Intra row spacing } \\
\hline$\underline{\text { Location }}$ & $\underline{10 \mathrm{~cm}}$ & $\underline{15 \mathrm{~cm}}$ & $\underline{20 \mathrm{~cm}}$ & $\underline{25 \mathrm{~cm}}$ \\
\hline Gitilo & $28.66^{\mathrm{c}}$ & $29.33^{\mathrm{bc}}$ & $30.66^{\mathrm{b}}$ & $32^{\mathrm{a}}$ \\
\hline Jarte & $25.11^{\mathrm{d}}$ & $27.33^{\mathrm{cd}}$ & $28.66^{\mathrm{c}}$ & $28.55^{\mathrm{c}}$ \\
\hline Lsd $(0.05 \%)=$ & & & & 1.38 \\
\hline CV\%= & & & & $\underline{5.44}$ \\
\hline
\end{tabular}

Numbers followed by the same letters are non significant difference at $0.05 \%$ probability

The analysis of variance on number of tiller produced per plant was shown significant difference on malt barely varieties, but intra row spacing was highly significantly $(\mathrm{P}>0.01)$ difference on malt barley crop. The interaction effect of location, intra row spacing and varieties were significant $(\mathrm{P}>0.05)$ difference on the number of tiller produced per plant (Table 4). The highest number of tiller produced per plant was (8.33) on Holker varieties at intra row spacing of $25 \mathrm{~cm}$ at gitilo study site. While the lowest number of tiller per plant was 3.66 on Ibon varieties at intra row spacing of $10 \mathrm{~cm}$ at Gitilo and Jaret study site. The variation in number of tillers produced per plant was due to soil fertility difference, genetic variability, agronomic practices and others. At wider plant spacing the malt barely crops were produced higher number of tillers per plant, because the competition among the plant for natural resources are very low.

The analysis of variance on spike length of malt barely crop was highly significant $(\mathrm{P}>0.01)$ difference on location, intra row spacing and varieties of malt barely. The interaction effect of location, intra row spacing and varieties were significant difference on malt barely crop. 
Table 5:- Interaction effect of location, intra row spacing and varieties on spike length on malt barley crop.

\begin{tabular}{|c|c|c|c|c|c|}
\hline \multicolumn{5}{|c|}{ Intra row spacing } \\
\hline Location & $10 \mathrm{~cm}$ & $\underline{15 \mathrm{~cm}}$ & $\underline{20 \mathrm{~cm}}$ & $\underline{25 \mathrm{~cm}}$ & $\underline{\text { Varieties }}$ \\
\hline Gitilo & $8.6^{\mathrm{c}}$ & $10^{\mathrm{b}}$ & $10.3^{\mathrm{b}}$ & $11^{\mathrm{a}}$ & Ibon \\
\hline Gitilo & $8^{\mathrm{b}}$ & $8.3^{\mathrm{c}}$ & $8.3^{\mathrm{c}}$ & $8.6^{\mathrm{c}}$ & Bahite \\
\hline Gitilo & $7^{\mathrm{d}}$ & $7^{\mathrm{d}}$ & $8^{\mathrm{c}}$ & $8.6^{\mathrm{c}}$ & Holker \\
\hline Jarte & $6^{\mathrm{e}}$ & $7.3^{\mathrm{d}}$ & $7.6^{\mathrm{d}}$ & $8.6^{\mathrm{c}}$ & Bahite \\
\hline Jarte & $6^{\mathrm{e}}$ & $6.6^{\mathrm{e}}$ & $7.3^{\mathrm{d}}$ & $7.6^{\mathrm{d}}$ & Holker \\
\hline Jarte & $5.3^{\mathrm{f}}$ & $6.6^{\mathrm{e}}$ & $7.6^{\mathrm{d}}$ & $7.3^{\mathrm{d}}$ & 0.8 \\
\hline Lsd 0.05\%= & & & & & $\underline{7.9}$ \\
\hline Cv\%= & & & & & \\
\hline
\end{tabular}

The mean followed by the same letters are non significant difference at $0.05 \%$ probability

The analysis of variance on the main effect of location, varieties and intra row spacing were shown significant $(\mathrm{P}<0.05)$ difference on plant height of malt barely crops on Table 3$)$. The interaction of effect of location, intra row spacing and varieties was non significance $(\mathrm{P}>0.05)$ difference on plant height of malt barely. The highest plant height $(105.8 \mathrm{~cm})$ was recorded at Holker variety of malt barley, at intra row spacing of $10 \mathrm{~cm}$, on gitilo study site. While the shortest plant height $(84.08 \mathrm{~cm}$ ) was measured on Ibon variety of malt barely at $25 \mathrm{~cm}$ intra row spacing at Jaret study site. The variation of plant height on malt barley crops were due to varietal difference among the varieties, soil fertility status of the study site, the effect of intra row spacing among the variety and variability of climatic condition at both study sites. The Gitilo study area is relatively high land site and get high amount of rain fall and low temperature so that the soil contain adequate amount of moisture for long period, due to this the plant continuous growth for certain period. Similarly wider intra row spacing plot holds sufficient amount of resource i.e the plant less compete for resource and the height of the crop relatively short as compared to those plant stressed resource on narrow intra row spacing.

The analysis of variance was shown significant difference on yield component and yield of malt barely. The main effect was significant difference on number of seed per spike of malt barely. The interaction effect was nonsignificant difference $(\mathrm{P}>0.05)$ on number of seed per spike of malt barely. The highest number of seed per spike was counted at intra row spacing of $(25 \mathrm{~cm})$ on Ibon variety of malt barely at Gitilo study site. But the lowest number of seed per spike was recorded at intra row spacing of $(10 \mathrm{~cm})$ on variety of Holker at Jaret study site. Intra row spacing was play a great role on number of seed per spike, at the wider intra row spacing the number of seed counted per spike was higher because of the plant get sufficient amount of resource element. So that number of seed per spike was dependent on intra row spacing variables, genotypes and other factors that influence the amount of yield produced per a plot.

Table 6:- Effect of intra row spacing of malt barely varieties at different locations on yield component.

\begin{tabular}{|c|c|c|c|c|}
\hline $\begin{array}{c}\text { Treatment } \\
\text { Location } \\
\text { Gitilo } \\
\text { Jaret } \\
\text { LSd } \\
0.05 \% \\
\end{array}$ & $\begin{array}{c}\text { Number of } \\
\text { seed per spike } \\
30.16^{\mathrm{a}} \\
27.42^{\mathrm{b}} \\
0.74\end{array}$ & $\begin{array}{c}\text { Thousand } \\
\text { seed wt (gm) } \\
33.08^{\mathrm{a}} \\
32.58^{\mathrm{a}} \\
\text { NS }\end{array}$ & $\begin{array}{c}\text { Dry bio } \\
\text { mass }(\mathrm{kg}) \\
23203.4^{\mathrm{b}} \\
24634.3^{\mathrm{a}} \\
800\end{array}$ & $\begin{array}{c}\text { Grain } \\
\text { Yield }(\mathrm{kg}) \\
3052.4^{\mathrm{a}} \\
2945.0^{\mathrm{a}} \\
\mathrm{NS}\end{array}$ \\
\hline $\begin{array}{c}\text { Intra row spacing } \\
10 \mathrm{~cm} \\
15 \mathrm{~cm} \\
20 \mathrm{~cm} \\
25 \mathrm{~cm} \\
\mathrm{LSd}(0.05 \%) \\
\end{array}$ & $\begin{array}{c}26.88^{\mathrm{c}} \\
28.33^{\mathrm{b}} \\
30.28 \\
29.66^{\mathrm{a}} \\
1.14 \\
\end{array}$ & $\begin{array}{c}32.16^{\mathrm{b}} \\
32.00^{\mathrm{b}} \\
33.33^{\mathrm{a}} \\
33.83^{\mathrm{a}} \\
1.1 \\
\end{array}$ & $\begin{array}{c}25616.7^{\mathrm{a}} \\
24177.8^{\mathrm{b}} \\
23310.7^{\mathrm{bc}} \\
22570.4^{\mathrm{c}} \\
1229\end{array}$ & $\begin{array}{c}3360.3^{\mathrm{a}} \\
3119.1^{\mathrm{b}} \\
2827.4 \mathrm{c} \\
2688.1 \mathrm{c} \\
224.1\end{array}$ \\
\hline $\begin{array}{c}\text { Malt barely Varieties } \\
\text { Ibon } \\
\text { Bahite } \\
\text { Holker } \\
\text { LSD0.05\% } \\
\end{array}$ & $\begin{array}{c}29.58^{\mathrm{a}} \\
28.62^{\mathrm{b}} \\
28.16 \\
\underline{0.95} \\
\end{array}$ & $\begin{array}{r}33.91^{\mathrm{a}} \\
33.29^{\mathrm{a}} \\
31.29^{\mathrm{b}} \\
\underline{0.91} \\
\end{array}$ & $\begin{array}{c}23362.8^{\mathrm{b}} \\
22751.7^{\mathrm{b}} \\
25624.1^{\mathrm{a}} \\
1031 \\
\end{array}$ & $\begin{array}{l}3064.28^{\mathrm{a}} \\
2917.13^{\mathrm{a}} \\
3014.70^{\mathrm{a}} \\
\quad \underline{\mathrm{NS}}\end{array}$ \\
\hline $\begin{array}{c}\text { Loc } \mathrm{x} \text { intra row } \\
\text { Loc } \mathrm{x} \text { Var }\end{array}$ & $\begin{array}{c}\mathrm{NS} \\
12.73 \\
\end{array}$ & $\begin{array}{c}\mathrm{NS} \\
\mathrm{N} \\
\end{array}$ & $\begin{array}{c}1.22 \\
13.36 \\
\end{array}$ & $\begin{array}{c}\mathrm{NS} \\
0.74 \\
\end{array}$ \\
\hline
\end{tabular}




\begin{tabular}{|c|c|c|c|c|}
\hline Intra row x Var & $\mathrm{N}$ & 0.89 & $\mathrm{NS}$ & $\mathrm{NS}$ \\
Loc x Intra row x Var & $\mathrm{S}$ & $\mathrm{N}$ & $\mathrm{N}$ \\
LSD0.05\% & $\mathrm{NS}$ & $\mathrm{S}$ & 0.38 & $\mathrm{~S}$ \\
Cv\% & 0.25 & 0.47 & $\underline{7.06}$ & 0.55 \\
& $\underline{5.44}$ & $\underline{4.5}$ & $\underline{10.26}$ \\
\hline
\end{tabular}

The mean followed by the same letters are non significant difference at 0.05 probability

The analysis of variance on the main effect was shown significant difference $(\mathrm{p}<0.05)$ on thousand seed weight of malt barely. But the cop was shown non-significant effect on the interaction of thousand seed weight. The highest thousand seed weight was measured (33.91 gm) at intra row spacing of $25 \mathrm{~cm}$ on Ibon variety of malt barely at Gitilo study site. The plant was get ample amount of resource element at wider intra row spacing like nutrients, light and water.

But the lowest thousand seed weight was measured $(31.16 \mathrm{gm})$ at intra row spacing of $10 \mathrm{~cm}$ on Holker variety of malt barely at Jaret study site. The difference in thousand seed weight on malt barley crop was due to resource limitation at narrow intra row spacing.

The analysis of variance on spike length was shown significance difference $(p<0.05)$ on main and interaction effects of malt barely (Table 3). The highest spike length interaction effect $(11 \mathrm{~cm})$ was observed at $(25 \mathrm{~cm})$ intra row spacing on Ibon variety of malt barely at Gitilo study site. But the lowest interaction effect on spike length $5.3 \mathrm{~cm}$ was measured at $10 \mathrm{~cm}$ intra row spacing of Holker variety of malt barely at Jaret study site. At wider plant spacing the malt barley crop use the resource efficiently and this resource help for the vegetative growth and increase the spike length of the crop. As intra row spacing of the malt barley crop was increased then the spike length was increased i.e spike length of malt barely is directly dependent on the intra row spacing of the crop. In average the highest and lowest amount of spike length $(8.6 \mathrm{~cm})$ and $6.98 \mathrm{~cm}$ ) was recorded at Gitilo and Jaret study site respectively. The differences in spike length at both the study areas are due to the variation in climatic condition and soil fertility status. Even if the same variety was gave difference spike length at different environmental condition, for instance in average Ibon variety of malt barely was measured $(9.98 \mathrm{~cm}$ and $7.45 \mathrm{~cm})$ spike length at Gitilo and Jaret site respectively. There is variation among the variety; at different plant intra row spacing and study areas, Generally Ibon variety of malt barely was gave higher amount of spike length than the others variety.

The analysis of variance on the interaction effect was significant difference $(\mathrm{P}<0.05)$ on number of tiller produce per plant of malt barely. But the interaction effect of location with varieties are highly significant difference $(\mathrm{P}>0.01)$ on number of tillers produced per plant. The highest number of tiller produce per plant (8.3) was counted at $25 \mathrm{~cm}$ intra row spacing on Ibon variety of malt barely at Gitilo study site. While the lowest number of tillers produced per plants (3.6) were counted at intra row spacing of $10 \mathrm{~cm}$ on Ibon and Holker varieties malt barely at both study sites. Generally the number of tillers produced per plant was directly proportion to intra row spacing of malt barely. When the spaces between the crops are wider the plants easily get adequate amount of resource and produce higher amount of tillers.

Relatively the numbers of tillers produced per plants 5.5 and 4.9 were registered at Gitilo and Jarte study sites respectively. The Gitilo study sites are more suitable for number of tillers produced per plant than Jaret site. Because the Gitilo study area have very fertile soil and conducive climatic condition I.e the altitude ranges 2800masl that suitable for the growth and development of malt barely crop than Jarte study site.

Among the varieties the highest number of tillers (6.8) was produced by Ibon variety of malt barely at gitilo study site, but produce lowest amount tillers 4.9 at Jarte farmer's field. While Holker variety of malt barely has produced high amount of tillers 5.8 at Jarte site, but the plant has produce lower number of tillers 4.8 at Gitilo site. Generally Ibon variety is more suitable at wider intra row spacing on Gitilo study site. But Holker variety is produce more number of tillers at wider intra row spacing at Jarte study site.

The analysis of variance on number of seed produced per spike was shown significant difference $(\mathrm{p}<0.05)$ on interaction effect of malt barley crop. The highest number of seed produced per spike (34.66) was observed at intra row spacing of $25 \mathrm{~cm}$ at Gitilo study site. While lower number of seed produced per spike on malt barely (24) was counted at $10 \mathrm{~cm}$ intra row spacing at Jarte study site. Number of seed produced per spike was directly proportion to intra row spacing on malt barely crop i.e when the spacing among the plant was increased or wider the plant easily 
get the adequate amount of natural resource like water, light and nutrient element that are help for propare growth and development of the plant.

The analysis of variance on thousand seed weight was shown significant difference $(\mathrm{p}<0.05)$ on main effect of intra row spacing and varieties on malt barely crops. While location and interaction effect of was non significant effect on malt barely crops. The highest thousand seed weight $(33.83 \mathrm{gm})$ was measured at $25 \mathrm{~cm}$ intra row spacing on Ibon variety of malt barley, but lowest number of thousand seed weight $(32 \mathrm{gm})$ was measured at intra row spacing of $15 \mathrm{~cm}$ intra row spacing on Holker variety of malt barely. The variations in thousand seed weight were recorded due to the difference of variety and space among the plant. At wider plant spacing the malt crops get sufficient amount of resource and this resource are directly converted in to the seed. Also certain varieties of malt barely like Ibon have bigger gain size and measured higher seed weight.

The analysis of variance on main effect of location, intra row spacing and varieties were shown significant difference on dry bio mass of malt barley crops (Table 6). But the interaction effect was non significant effect ( $>0.05)$ on dry bio mass of malt barely crops. The highest dry bio mass was measured at $10 \mathrm{~cm}$ intra row spacing on variety of Holker at Jaret study site. While the lowest dry bio mass was measured at $25 \mathrm{~cm}$ intra row spacing on Bahite variety of malt barely at Gitilo study site. Generally at narrow plant spacing malt barely crops was measured higher amount of dry bio mass. At wider plant spacing the crops were grown vegetative and measure less amount of dry bio mass per plot. Dry bio mass of different varieties of malt barely crops were varied from variety to variety i.e certain malt barely plants like Holker variety is produced more number of tillers and higher in plant height due to this morphological characteristic the plant measured higher amount of dry bio mass than others variety. Other factors that influence the dry bio mass of malt barely crops are study site. Different study site have different environmental condition and soil type so that different variety need different climatic requirement and the dry bio mass of that crops are vary.

The analysis of variance on location, varieties and interaction effect were shown significant difference $(\mathrm{p}<0.05)$ on grain yield. But the main effect of intra row spacing was significant difference on grain yield of malt barely crop. The highest grain yield was measured $10 \mathrm{~cm}$ intra row spacing on Ibon variety of malt barely at Gitilo site. But the lowest grain yield was measured at $25 \mathrm{~cm}$ intra row spacing on Bahite variety of malt barely at Jarte study site.

Table 8:- Interaction effect of location with varieties on grain yield of malt barely

\begin{tabular}{|c|c|c|c|}
\hline \multicolumn{3}{|c|}{ Varieties of malt barely } \\
\hline Location & Ibon & Bahite & Holker \\
\hline Gitilo & $3175.8^{\mathrm{a}}$ & $2961.8^{\mathrm{e}}$ & $3019.5^{\mathrm{c}}$ \\
\hline Jarte & $3052.7^{\mathrm{b}}$ & $2872.4^{\mathrm{f}}$ & $3009.8^{\mathrm{d}}$ \\
\hline Lsd $0.05 \%=$ & & & 0.74 \\
\hline Cv\%= & & & 0.74 \\
\hline
\end{tabular}

The mean followed by the same letters are non significant difference at $0.05 \%$ probability

The analysis of variance on harvest index was significant difference $(\mathrm{p}<0.05)$ on main location, intra row spacing and varieties of malt barley crop. The highest harvest index $0.127 \%$ was observed at $10 \mathrm{~cm}$ intra row spacing at Gitilo study site on Ibon variety of malt barely.

\section{Conclusion:-}

Malt barely is one of the cereals crop dominantly cultivated at high land area of Ethiopia for beer factors. Ethiopia malt factors gain the malt seed from the broad country for the beer beverage in high costs. Recently the malt factors put agreement with barely producing areas the factors give service like input and others facility for the farmers in order to get quality malt seed from the farmers with better price. So those farmers at the high land areas of Ethiopia like Gonder and Bale and Arsi areas benefited by producing quality malt barley and sale with high cost as compare to other cereal crop. Know a day different model farmers are produced malt barely crops on his plot area of land. Malt barely varieties are suitable to grown on different agro ecology areas. The varieties are relatively more diseases resistance and high yielder than cereal crops. In general the amount of yield gain at both study sites and among the varieties are non significant difference, but have significant effect on intra row spacing of the crops. Relatively the amount of yield gain from Ibon variety is higher Holker and Bahit. The highest amount of malt barely yield $(3,352.3 \mathrm{~kg} / \mathrm{ha})$ was registered at $10 \mathrm{~cm}$ intra row spacing, while the lowest malt barely yield $(2,688.1 \mathrm{~kg} / \mathrm{ha}) \mathrm{was}$ measured at intra row spacing of $25 \mathrm{~cm}$ on Ibon variety of malt barely. Therefore Ibon variety is more productive at 
both study sites, bigger in grain size and early matured types moreover the researchers is recommended for those farmers produce malt barely crops at both study sites.

\section{Acknowledgment:-}

First I would like to thanks my organization to give such type of chance to conduct an experiment on malt barley, and second my thanks goes to Qulumisa Agricultural research center to offering the improved malt barely seed freely.

\section{Reference:-}

1. Acqual, G. 2005. Principles of crop production. Theory, techniques and technology $2^{\text {nd }}$ edition. Published in India.

2. Asmare Yellew, Alemu Hailiye, Alemayehu Assefa, Melkamu Ayalew, Tessema Zewudu, Berihane Assayegn \& Halima Hassen. 1998. Barley production practices in Gojam and Gondar. In: Barley based farming system in the high lands of Ethiopia. Addis Ababa, Ethiopia. pp. 67-89.

3. Brady,C.N. and R.R.weil. The nature of properties of soil. $12^{\text {th }}$ edition.

4. CSA, 2010. Central statistical agency. Annual exporting cereals crop report, Addis Ababa.

5. CAST, 1988. Effective use of water in irrigated agriculture. TASK FORCE REPORT. no.113. Ames,I.A: Council for Agriculture Science and technology.

6. EIAR, 2007. Ethiopia Institute of Agricultural Research, Annual released seed report.

7. Gomez, K. A. and A. A. Gomez. 1984. Statistical procedure for Agriculture Research ( $2^{\text {nd }}$ edition). John wiley. Inc., New York.

8. HGZAB. 2010. Annual report of zonal crop production. Horro Guduru Wollega Zone Agriculture Bureau.

9. MoARD. 2008. The Ministry of Agriculture and Rural Development Crop Variety Register. ISSUE No.11. Addis Ababa, Ethiopia.

10. Miller,W.R. and D.T.Gardner. 1999. Soils in our Environment. $9^{\text {th }}$ edition. Upper saddle Revir, Nj:Prentice Hall.

11. ORDA (Organization for Rehabilitation and Development in Amhara), 2008a. Baseline survey of six malt barley potential woredas of north and south Gondar zones of the Amhara region, Ethiopia.

12. ORDA (Organization for Rehabilitation and Development in Amhara) 2008b. Ethiopia: Malt barley value chain study. Options for Growing a new channel in Amhara Region. Bahir Dar, Ethiopia.

13. Reddy.T.Y. and G.H.Sankaraddy. 2010. Principles of Agronomy. Printed in India.

14. http://.www.extension.umn.edu/distribution/cropsystem/DC2548.html. Barely growth and development. 